\title{
Freelance Journalists' Ethical Boundary Settings in Information Work
}

\author{
Martina Ladendorf
}

\begin{abstract}
The borders between the media genres journalism and information or PR are blurring, and this development is especially noticeable among freelance journalists. How does this affect freelance journalists, particularly their ethical reasoning? Thirteen interviews with freelancers living in a peripheral northern county in Sweden were analyzed, using a combination of discourse analysis and narrative theory methods and a virtue ethics theoretical framework. It was found that 11 out of 13 informants worked occasionally or regularly with information-type assignments. To sustain the informants' professional roles and selfidentities of integrity and impartiality, having boundary settings between, first, information/PR and journalist roles and, second, information and journalist type assignments was crucial. It was evident that individual ethics had replaced professional principles. The freelancers reflexively process media industry constraints, together with their everyday working conditions, in a situation where the ideals and norms of the profession constitute the background for their individual action ethics.
\end{abstract}

Keywords: freelance journalists, information work, qualitative interviews, Neo-Aristotelian virtue ethics, discourse analysis, narrative theory

\section{Introduction}

Freelance journalists are a particularly vulnerable group in the media industries, and therefore well worth studying if one is interested in changes in journalism. Economic cutbacks in the media sector diminish the chances of employment for journalists, and consequently the numbers of atypical workers such as freelancers are growing worldwide (IFJ 2006). However, “[journalism] research tends to overlook particular categories of news workers. It predominantly charts the professional cultures of privileged full-time news reporters over casualized, multi-skilled, and free-lance journalists" (Wahl Jorgensen \& Hanitzsch 2009: 12). ${ }^{1}$ In the dominant journalism discourse, the trustworthiness or ethos of a journalist is seen as compromised if $\mathrm{s} /$ he does information work, PR or - even worse - work in advertising. This could be seen, for example, when Christina Kennedy, chief editor of Scoop, the magazine for Swedish investigative journalists, accused freelancers who worked in information of being unethical, and demanded an "ethical label" on magazines and journalists, the goal being to ensure that the journalists writing for the magazines would not also work in information (Kennedy 2009, see also Kvist 2009). The journalism role is hereby kept separate from the information worker (see also Larsson 2009), even though, according to the debates in Scoop, and in the 
Swedish journalist union, borders between information and journalism are blurring and many freelance journalists seem to be doing information work. How, then, do freelance journalists reason about the issue of performing information work? Does performing these work tasks affect journalists' professional roles and self-identities, and how do freelancers relate to the professional principles of journalism? To answer these questions, thirteen qualitative interviews with freelance journalists in northernmost Sweden were analyzed. The informants were chosen randomly, without the question of information work in mind.

The article starts out by describing the theoretical framework, mainly stating the ontological foundation of the research, which is followed by a description of the research material. Thereafter follow sections about, first, journalism ethics and, second, journalism ethics research, which includes a discussion on virtue ethics and its use in journalism ethics research. The sections on previous research and theory are followed by research results and analysis, which are divided into four sections: 1) how the freelancers relate themselves to entrepreneurship and entrepreneurial discourses, 2) ethical boundary settings of freelancers, 3 ) when survival is deemed more important than being a virtuous journalist, and 4) some consequences of individual ethics, which are followed by a concluding discussion.

\section{Theoretical Framework and Strategies of Analysis}

As a strategy of analysis, a combination of critical discourse theory and narrative theories was used. As has been shown, there exists a normative discourse about journalism, which is connected to an understanding of the role of journalism in society. However, I considered it unproductive to use a normative framework in journalism research (see also Kunelius 1996: 62), and instead started out from the life stories of the freelancers, seeing these as parts of a larger structure. The main objective was to study the structure through the statements and stories of individuals, and not by judging them from the perspective of normative ethical principles. This aim to some extent clashed with the use of virtue ethics, which is a normative theory. However, I distinguish between norms as inner standards, and the normative judgments made by outsiders, and therefore focused on inner norms such as individual ethics, which of course were highly influenced by collective norms. By discourse theory, I mean the ontological idea that humans constantly relate to, the notion that they position themselves through or against a number of discourses, and that there is no meaning outside discourse (Laclau \& Mouffe 2001). The informants' statements were seen as expressions of existing discourses rather than as mere individual standpoints. Moreover, I see journalism as a specific discourse order (Foucault 1993), which is forever changing and which appears to be different in different contexts. Pertti Alasuutari (1997) proposes a discursive view in life-story research. He sees discourses as interpretative repertoires or linguistic resources used to create a sense of self. This view is similar to Anthony Giddens' (1991) perspective, where individuals in late modernity are seen as dependent on creating a coherent biographical narrative. The freelancers' ethical reasoning provides examples of such a narrative, which is intimately connected to their professional identities. Giddens' (2008) theory of structuration, which connects the micro-level to the macro-level, is suitable for the analysis of life stories, because these stories connect the subjective level to the structural level. In 
late modernity, individuals are reflexive, constantly asking themselves how they should live (Giddens 1991). People ask themselves why they do what they do, something that has discursive aspects and is connected to human knowledge. If one asks people what they do, they can make an account of this and provide discursive interpretations. The choices they make are connected to lifestyles, something that is highly relevant with regard to media workers in general and freelancers in particular. Mark Deuze (2007: 1pp) uses Bauman's term "liquid life" to describe the working life of today's media workers, and the concept of individualization to describe a process whereby social institutions are disintegrating and increasing demands are being put on individuals instead of on organizations (see also Beck 2000). Media workers in late modernity lead a "portfolio lifestyle" (Deuze 2007: 11), committing only to projects, short-term goals in a foreverchanging working environment. Ulrich Beck (2000) connects this to the ideology of neo-liberalism, and describes many of the self-employed in this way:

Muddling through describes a new society of people working on their own account. These one-man or one-woman businesses have only a limited amount in common with traditional notions of entrepreneurship. Besides, their objective is much more likely to be the moulding of a life of one's own than conquest of the world market. (Clermont \& Goebel, cited by Beck 2000: 55)

\section{The Interviews}

The area of Norrbotten was chosen for reasons of convenience, but also because it is a well-defined region and therefore suited for a case study. Norrbotten is the northernmost county of Sweden with under 200,000 inhabitants and an area of 26,671 square kilometers. The province lies in a media shadow in many respects, but the distance to the media centers of Sweden has made the province exotic and interesting to the national media, according to the interviewed freelancers. Also, national media editors sometimes feel guilty for not representing the whole of Sweden. The results show that geographical position, combined with great distances between towns and places, is one of the most important advantages for freelancers working for the national media, as it is too expensive for media companies to send their own employees up north. However, the peripheral province of Norrbotten has a media center in Luleå with public service TV and radio, the commercial but terrestrial channel TV 4, and local daily newspapers NorrbottensKuriren (bourgeois - liberal) and Norrländska Socialdemokraten (social democratic). The majority of the interviewees lived in Luleå, but a smaller coastal town, and the inland areas were also represented. Thirteen informants were chosen using the following criteria: They were to reside in Norrbotten and to earn their living through freelance journalism. However, they could have time-limited or part-time employments in local media companies. Only one interviewee did not meet these criteria, supporting himself with unemployment benefits, having applied but not been accepted for a "Start your own business" grant. He was, however, interesting for the analysis, in ways that will be revealed later on. The journalists were between the ages of 39 and 61, seven males and six females; writers, TV and radio journalists were represented, although journalists doing press and assignments dominated. All interviews were conducted and transcribed by the present author during 2008 and 2009. After preliminary analysis, there was a meeting with a group of freelance journalists in November 2009 where the 
results were presented. The group was not identical to the informant group, although some informants were present, but can be seen as a reference group that strengthens the validity of the research by testing the preliminary results on the researched group. Their feedback has been incorporated into the analysis.

The method of material collection can be called (working) life interviews, following the procedures of narrative theory and life story interview research (Atkinson 1998; Johansson 2005; Maynes et al. 2008). This method has been used successfully to connect the subjective to the structural level (Maynes et al. 2008) and is therefore suitable for trying to get not only a deeper understanding of the work situation and the personal choices of individual reporters, but also their positions on the job market and in society. Informants spoke about why they became journalists, how they started their own businesses, but also told about their private lives. The interviews were between thirty minutes and three hours long, and all started with the question: "Could you tell me about your life, focusing on your work?"

All informants had the opportunity to read the transcripts, and their corrections were used in the citations. The interview citations presented here were edited, mostly with regard to anonymity, and of course translated from Swedish to English. The names of clients, media companies, etc., which would make it easy to identify the informants, were not revealed. The research subject raises ethical considerations concerning confidentiality, because everybody knows everybody in Norrbotten. Also, some revealing facts have been changed and fictionalized.

\section{Journalism Ethics}

The word ethics comes from the Greek word ethos, meaning character, custom and behavior, signifying the doctrine of good and evil (Bivins 2004: 21).

Ethics is the analysis, evaluation and promotion of what constitutes correct conduct and virtuous character in light of the best available principles. Ethics does not simply ask how to live well. It asks how we should live ethically, that is, in goodness and in right relation with each other, a task that may require us to forego personal benefits, to carry out duties or to endure persecution. Ethical reasoning is about how people interpret, balance and modify their principles in light of new facts, new technology, and new social conditions. (Ward 2009: 295)

One can distinguish between professional principles and individual ethics (Bivins 2004: 21). In the professional principles of the Swedish Union of Journalists (SJF), information work is not mentioned specifically, but questions of journalists' integrity and their positions as free and independent journalists are. It is, however, left to interpretation what compromises this position. In the requirements for who can be accepted as a union member, it is even more explicit:

To become a member of the union of journalists, you have to be employed or freelance with mostly journalistic tasks. This includes independent production, selection, evaluation, or revision of editorial material for mass media, or other journalistic assignments. This involves anyone working with photography, writing and editing, trainee, student of photography, artist, proof-reader, telephone operator, picture editor, archivist, researcher, graphic designer and student of graphic design, editor, reporter and/or pro- 
ducer in radio/television, and photographer and editor in television. (SJF, Bli medlem ("Become a member", author translation)

Here, information work is not mentioned, as the text focuses on journalistic and editorial work. It is not possible to become a member if one works predominantly with information. The rules also state that to become a member, one has to work for the most part with journalistic assignments and have a monthly income of at least SEK 7,800, for at least four months. According to one of the informants, one has to work 50 percent with journalistic assignments in order to be accepted, but after acceptance one can do less than 50 percent without being thrown out, as is the case with many freelancers in Norrbotten. In 1997, the Norwegian Journalist Union excluded information workers in what has been called an "ethical cleansing" (Ottosen 2004: 207-219), because the information officers were seen as the opponents of journalists. Marianne Edlund (telephone conversation 03-12-2009) at the Swedish Union of Journalists told me that the 1992 congress made the decision not to accept information officers as members, but did not throw out existing members. According to Edlund, the way of reasoning was that there was a difference between journalists and information workers, where journalists were seen as having a more independent role, and their duty was to readers and viewers rather than to the owners of media businesses. The information worker represents his/ her employer, which is not a media company, and therefore s/he is less independent than a journalist is. The guidelines of the Swedish and Norwegian unions show that it is considered controversial when a journalist performs information work, notwithstanding the fact that it is extremely common among the freelancers in Norrbotten, according to my results.

\section{Journalism Ethics Research}

In journalism research, studies on ethics are numerous (for example Ekström \& Nohrstedt 1996; Börjesson 2007; Herrscher 2002; von Krogh 2009; Ward 2009), but the focus is seldom on ethics concerning information work. Much of the research on media ethics focuses on applied ethics, assessing accountability or responsibility, while a more extensive use of appropriate philosophical theories is less common (Starck 2001), except for Neo-Aristotelian virtue ethics (MacIntyre 2008; Klaidman \& Beauchamp 1987; Lambeth 1992; Quinn 2007; Borden 2007), which will be discussed later.

Inger Orre's (2001) dissertation studies reporters over the age of forty. Among her interviewees were both employed journalists and freelancers, but the number of freelancers grew during the study, from five to seven of the total of seventeen. Some of the reporters in Orre's group had accepted information assignments, which some of the other participants approved of and others criticized. The interviewees claimed that this would not have been accepted in the 1970's, which suggests an adjustment to market forces. One journalist, who was self-employed, called himself "producer" instead of journalist, in order to escape moral dilemmas and do lucrative work in information, advertising, etc. Another journalist declared that it was important to know the differences between information workers and journalists, to make it obvious on whose behalf one is speaking. However, it was evident that these boundary settings were often unclear. The interviewee who was most open to information assignments explained that he followed his own conscience rather than the conventions of the 
journalist profession (Orre 2001: 141), an inclination that was also found among the informants in my own study.

Journalism researchers Ekström and Nohrstedt (1996), in a qualitative interview study, come to the conclusion that journalists' capacity for ethical reasoning is low. Furthermore, they distinguish between ethical ideals and journalism practice, or action ethics. Ideals are normative perceptions such as those appearing in the SJF principles and are based on ideologies. Action ethics is what journalists do, which is contextually defined (Ekström \& Nohrstedt 1996: 16 pp). These concepts will be used as a theoretical framework for the discussion about ethics, along with the concepts professional principles and individual ethics and Neo-Aristotelian virtue ethics. The first to use virtue ethics in journalism studies were Klaidman and Beauchamp (1987), who have been followed by other researchers (Lambeth 1992; Gardner et al. 2001; Borden 2007; Quinn 2007). Virtue ethics in journalism is an internalization of a regulative ideal concerning how good journalists should behave and an instinctive sense of what constitutes good actions for journalists. Journalists should behave with integrity, showing good character. Formal rules and regulations can only be used as guidelines, because just following rules could produce the appearance of ethical behavior, without there being any real underlying ethical principles. A central concept in virtue ethics is phronesis, practical wisdom or moral knowledge, "being a virtuous person requires having intimate knowledge of what is good, not just abstractly, but through training and experience in a given role" (Quinn 2007: 172). Researchers (Klaidman \& Beauchamp 1987; Gardner et al. 2001; Borden 2007) designate the virtue of truthfulness as telos or "ultimate end of practice" (Borden 2007: 23) in journalism, even though the concept "truth" has been seen as problematic in both journalism and journalism research (Kovach \& Rosenstiehl 2007: 35pp). Writing about virtue ethics and professional roles, Oakley and Cocking state that: "having a particular virtuous disposition requires internalising a certain normative standard of excellence, in such a way that one is able to adjust one's motivation and conduct so that it conforms, or at least does not conflict with, that standard" (Oakley \& Cocking 2001: 28). This will lead to "human flourishing" or eudaimonia, where the virtues are valued because of their intrinsic qualities, not because of their effects. Being virtuous leads to living a good life. In virtue ethics, doing good is valued higher than doing the right thing (in contrast to utilitarianism), as the virtues themselves are seen as more important than the outcomes of certain actions. Borden (2007) and Gardner et al. (2001) have pointed out that real-life examples of virtuous practitioners are intimately connected to virtue ethics, which functions by example. Next, the article will discuss what happens to professional ideals and virtues in the everyday working life of the freelance journalists.

\section{Studying the Freelancers}

In the following sections, the interviews are analyzed. The section on entrepreneurial discourses lays the foundation for understanding the positions of the freelancers on the labor market. The following section studies their ethical boundary settings, which are essential to professional identities. Thereafter follows a discussion on when survival takes priority over ethics, and an analysis of some examples of fateful moments (Giddens 1991): life-changing events for some of the interviewed journalists. 


\section{Journalists as Entrepreneurs}

When journalists decide to go freelance, they most often start their own firm. One of the informants did freelance work for a while without having his own firm, but was still considered to be a freelancer by the Swedish Public Employment Service, which made it impossible for him to get unemployment compensation. Thus, having a business of one's own seems to be the only legitimate way to work as a freelance journalist. ${ }^{2}$ According to some of the informants, the role as journalist and the entrepreneurial role are in a state of opposition. What happens when a journalist decides to become self-employed? Some informants saw this as unproblematic and as a merely economic aspect. Others embraced their new identities as entrepreneurs. One interviewee was critical of freelancers because he saw them as "bad business owners", seeing themselves as freelance journalists and wanting to organize in the union. He thought they were unprofessional, still maintaining an employee's state of mind. Furthermore, he criticized some freelancers who were supported economically by their husbands/wives, or did other kinds of work on the side. According to the informant, the problem was that they had not developed entrepreneurial identities. An anti-entrepreneurial discourse, where selling and making money were considered morally objectionable, was apparent in the statements of some informants and was considered something that could lead to a self-identity crisis for the freelance journalist. However, this discourse has been challenged by an oppositional discourse that was apparent in the material and that has become more and more dominant: the entrepreneurial discourse. The latter emphasizes the responsibility of the individual: it pictures individual action as a road to success, and can be linked politically to neo-liberalism, having a great deal in common with Beck's (2000: 55) concept of individualization. As the citation beneath reveals, the entrepreneur and journalist roles collide in many ways:

Journalists have had a negative view of corporations, businessmen, business executives, the big ones, those they should scrutinize, should they really become one of those themselves, suddenly? Yes, in these days maybe one has to. [Mm] In former times, the world was divided in a societal structure with the priest, the vicar, and the director and the local government commissioner, and then there were journalists scrutinizing them. [Mm] But today maybe one has to be a businessman equal to other businessmen. I feel that it has been a support for me that I have felt like an equal opponent, no matter whom I chose to interview.

I see the entrepreneurial discourse as a highly ideological one, which is often used to displace responsibility from employers and government to individuals. However, it can also be empowering for the freelancers themselves. The latter can be seen in the citation, where the informant saw it as a strength to be a business owner, because he saw himself as an equal to other business owners. A recurring expression in the interviews was the term "free person"; to be a journalist business owner is to be free. It is, however, important to point out that only the strong survive in an increasingly hard society. The price they pay is worry and uncertainty, not least when it comes to finances. When meeting with the freelancers' club of Norrbotten, the citation above generated a lively discussion, as many saw this as a very antiquated view. They instead saw being an entrepreneur as something positive. Some also pointed out that they were first and foremost journalists, and thereafter business owners. One journalist cautioned against constructing employment as the norm, and freelancing as an anomaly. The conclusion is that there 
are a variety of opinions about this among the freelancers. There exist two competing discourses, and for the time being, the entrepreneurial discourse has the upper hand. In the words of Mark Deuze, the freelancers "express a sense of mastery over their lives, interpreting their professional identity in this context in terms of individual-level control and empowering agency" (2007: 24).

\section{Freelance Journalists' Ethical Boundary Settings}

Eleven out of thirteen informants had accepted work assignments in areas they themselves judged to be information. As borders between journalism and information are blurred, this was sometimes a personal definition. Some had done a small amount of information work, mainly for public authorities, whereas others had been information officers at large companies. Some had worked with so-called company magazines, or even composed texts for advertising. The latter were an exception, and the two informants who had done it pointed out that the products were uncontroversial or even commendable. One common type of assignment involved documenting conferences for companies, authorities or organizations, something the informants called bread-and-butter assignments. Some also worked as moderators or masters of ceremonies. One of the freelancers told about being contacted by lobby groups that wanted him to place customized material in different publications, without telling newsrooms or editors that this material was paid for by so-called spin doctors. This had happened repeatedly just prior to the national elections. This particular freelancer had declined the offers, because he saw them as unethical, but pointed out that the work always got done by other, less scrupulous journalists.

The material shows that it is considered controversial for freelancers to accept information assignments, but at the same time individual freelancers thought that, if they set up certain boundaries, they could take such assignments without hurting their integrity and impartiality. These boundary settings are quite similar, but there are also some differences in the informants' arguments. The journalists distinguish between journalism, information and advertising. One informant mentioned a town information magazine that reported an increase in air passengers and a decrease in unemployment, but not the opposite. Furthermore, in journalism, one reports the bad news, and in advertising only the good news. Information is somewhere in between journalism and advertising as regards neutrality and reporting facts. Advertising is less nuanced than information. The informant himself felt that he could distinguish between the different genres and adjust. The same informant reported that even though he accepted working for the town magazine, something he himself deemed to be information work, he would never write for a tabloid, because he thought these were examples of bad journalism. Other informants, in contrast, were happy to write for the tabloids, and even saw these assignments as high-status jobs. This suggests that an individual ethic has replaced professional principles among the interviewed freelancers. Another informant who had worked as an information officer for a long time told about the differences between being a reporter and working in information. He saw the information officer role as two-sided, in that a journalist is curious and wants to know and report as much as possible, while an information officer sits at board meetings and knows a lot, but cannot report much. Management is very secretive, but to earn the trust of the journalists one has to share more than they are comfortable with. Journalists and information officers are seen as 
opponents, but there is mutual respect. The role of the information officer is seen here as an intermediary between management and the media. There is, however, a great difference between working for a company and critically investigating it, which makes the informant draw a line between the information officer's role and the journalist's role. Everything the information officer writes about the line of business of his company is intended to be in support of the company, and therefore he cannot do journalistic jobs about the trade. This is a question of integrity for him, being 100 percent trustworthy as the company's spokesperson and 100 percent trustworthy as a journalist. His argument paints another picture than the journalism discourse described earlier, which claimed that the same person could not occupy both these positions. According to the dominant journalism discourse, the journalist turned information worker has switched sides, and is no longer trustworthy as a journalist. The freelancers stated that although it was important to maintain boundaries between information work and journalistic assignments, it was also possible to navigate between different types of assignments without losing their integrity. This suggests that professional principles have been replaced by an individual ethic, which can also be seen in the results of Orre (2001: 146).

Two of the freelancers said they had written articles about companies because the companies had purchased advertising space in the magazine, something that is deemed unethical by the Swedish Union of Journalists. These journalists had to choose between ethics and survival. The uncertainty of living freelance made them accept jobs they themselves saw as ethically indefensible. At the same time, many of the informants thought that these types of jobs, together with company magazines and customer magazines, were rather like journalistic assignments, and in some cases even held a higher quality than journalistic texts. This corresponds with research maintaining that the quality of journalism has declined, due to commercialization and re-organization in the media businesses (Underwood 1993; McManus 1994; Schudson 2003: 117pp; Murdock \& Wasko 2007; Borden 2007; Nygren 2008). Something many mentioned is that it is very easy for public relations departments to get the media to put forward their messages (see also Davis 2003; McNair 2008: 143 pp; Larsson 2009). The decreased quality of journalism is used as an argument for working with journalistic assignments that border on information work, because the line between information and traditional journalism is becoming indistinct. However, the essence of the argument concerns integrity and how to maintain it.

The two journalists who had written texts for advertisements (one job per person, in the context of long careers) reasoned differently from each other. One interviewee criticized the common view that journalistic integrity is seen as synonymous with refusing to work in advertising. He thought that journalistic integrity meant being accountable and trustworthy with regard to the audience, and building a relationship with them. However, if a journalist had promoted a product, s/he could not do a journalistic assignment about the same product. This was the most common line of ethical argument in the research material. Furthermore, trustworthiness was also associated with the journalist's individual ethics, and whether or not s/he found the products morally questionable. The other interviewee thought she was obliged to investigate products she had previously promoted, should the situation arise. The latter is, however, an unusual line of argument. Her belief was that a journalist should not form intimate bonds with clients or sources. This particular journalist had renounced new friendships as a way to maintain impartiality. Another interviewee had the same line of reasoning, and refrained 
from socializing with people in the sector she covered as a journalist. This shows that ethical considerations can go further than choosing which assignments to accept. An older, male journalist had a different strategy; he was friends with everybody, but did not let these friendships get in the way of reporting or dismissing his acquaintances:

And I have never, sure, I am pretty social, and people tell me things in confidence, but I have no obligation to people, my loyalty is to the readers. And always, what I have gotten to know I have written, because I am loyal to the readers, nobody else. And then they say, "Do you understand the consequences?" Oh, yes, I understood, but I wrote it anyway. I do my job, end of story.

Another line of reasoning is to forgo being a member of political parties or organizations. These journalists share an ideal of impartiality and independence, which results in their journalist ethics affecting their private lives. Koljonen distinguishes between the journalist as active agent and passive observer: "The observer journalist remains autonomous also in his free time; an outsider in relation to everything that might call into question his own idea of independence" (Koljonen 2009: 12). The ideal of objectivity therefore can be seen as strong in these particular informants. There are also examples of interviewees declining information work if it would affect their trustworthiness as investigative reporters. According to one interviewee, a freelancer, a free lance, is in many ways a mercenary, and his/her loyalty is sold. Information that is obtained in the employ of a client cannot be used for investigative reporting. Therefore, journalists must decline offers that would restrict them as writers. In these boundary settings, individual ethics prevail over professional principles. These ethical considerations are made on a personal level, and sometimes survival is deemed more important than ethics. Even though individuals set up different boundaries, there are some overall principles: integrity and impartiality. Journalistic integrity and impartiality is maintained by keeping different activities or subject areas apart, or by not creating bonds of loyalty to clients or others.

\title{
First Comes Survival, then Journalism Ethics
}

Some of the informants told about accepting assignments they did not feel comfortable with. It seemed that being responsible for their own support, but often also their families, sometimes forced them to stretch their ethical boundaries. The next citation summarizes most of the interviewees' attitudes toward information work, even if they, as has been shown, made different ethical boundary settings concerning what assignments to accept:

\begin{abstract}
And that's precisely what I used to say when talking about journalist ethics and stuff like that, the most important ethic for me is to support myself. Not to, I mean if I do supplements, information magazines and company magazines, it's not the traditional types of journalism, but the overriding thing is that I survive and that society doesn't have to support me, that's an important ethic.
\end{abstract}

This informant also said that the freelancers did not choose to do information work, because doing this type of work was the only way they could survive. Traditional news work, especially for local dailies, was poorly paid, whereas the jobs he usually did were better paid. Another informant positioned himself as a business owner, creating another job opportunity in Norrbotten, to justify the kind of work he did. For many freelancers, it is difficult to survive on editorial content. This seems to be most noticeable for journal- 
ists who mainly work for the local market. The two journalist who said they had not done information work produced material for the national market. One of the latter reported that she had been writing for a few publications on the borderline between journalism and information, but had chosen to see them as journalistic. The other was the only one in the sample who did not generate an income large enough to support himself, and who did not have his own firm because he had been denied a "start your own business" grant. His motive for freelancing was to do prestigious work to enhance his CV and thereby become eligible for high-status journalist positions. Doing advertising or information work could interfere with this plan, because future employers would object to it.

These findings raise important questions. Is journalism a vocation or a way to earn one's living? According to Sandra Borden (2007: 49 pp), one of the requirements of a profession is that it is occupational, in other words, it should make it possible to earn a living. In the research material, the vocational and occupational aspects are in conflict. Using virtue ethics, one could interpret this as a role conflict between being a virtuous household breadwinner, father/mother, wife/husband or citizen (able to support oneself and not dependent on the state) and a virtuous journalist (independent, autonomous, truthful, untainted by commercial considerations, etc.). According to Oakley and Cocking (2001), there can be a conflict between the requirements of a role and an individual's general flourishing. The journalist thus has to balance his/her roles in a way that leads to eudaimonia (flourishing life). The life stories of the freelancers tell of a quest to achieve this way of life. Most of them describe freelancing as a way to balance working life with family life, and working time with free time. The professional role as a journalist entails certain ethical principles that are internalized by the virtuous journalist, leading to excellence of character. Some previous research has focused on judging individual journalists as ethical or unethical. I see this discussion as less productive than a discussion of media industry structures. I believe it is wrong to put the blame for developments in the media industry on individual journalists, even though they of course have responsibilities and obligations; I would rather talk about the possibilities for leading a flourishing life as a journalist.

\section{The Consequences of Individual Ethics}

The analysis suggests that the informants often use ethical reasoning when deciding how to act. In the interviews, there are many examples of setting up boundaries between different kinds of jobs. In their working lives, they occasionally act contrary to these criteria, but solve the dilemma in different ways, for example by not appearing with their names under texts that they have written but that have been changed by others in ways they do not approve of, or by demanding better pay for ethically questionable jobs. A freelancer is positioned differently than an employed journalist: $\mathrm{s} / \mathrm{he}$ is free, but also more vulnerable. Some of the interviewees told about occasions when they were forced to take a stand, which sometimes had consequences, including losing their jobs. Here, they display the virtue of courage. In narrative theory and the life interview method, one often talks about turning points. These are crises or crucial events when things are pushed very far and the character of an individual is revealed or exposed (Johansson 2005: 319). A term used by Giddens is fateful moments, when "individuals may be forced to confront concerns which the smooth working of reflexively ordered abstract systems normally keep well away from consciousness" (Giddens 1991: 202f). Examples 
of fateful moments are birth and death, weddings, choice of career, etc. Taking a stand as a journalist is an example of such a moment.

\section{Fateful Moment One: Leaves the Editorial Office Never to Return}

A recently graduated journalist gets a summer job at a paper where there is a labor dispute. One night the chairman of the board comes in and tells the night editor to leave her keys and the editing room. Then the interviewee does something she to this day is proud of. She says: "Then I'll leave too", and after her trot seven printers. As a consequence she is deemed a revolutionary and has a hard time getting a new job.

\section{Fateful Moment Two: Confronting the Boss}

An older journalist has a trial period of employment with a periodical. The boss is very controlling. The journalist cannot stand it so he confronts the boss with specific questions, to test him, and as a consequence he is fired.

\section{Fateful Moment Three: Does not Want to Be the Boss}

A journalist works as the manager in a media company that is downsizing. In the position as manager, he has to carry through changes in the organization, and he finds himself further and further away from journalistic work. At last he has enough and quits, and starts working as a freelancer.

\section{Fateful Moment Four: Critical of Management}

A journalist works at a local daily, which has been sold and given new management that the journalist does not respect. The journalist is critical, confronts the boss, and finally quits because he gets redundancy payment, and starts working as a freelancer.

Conflicts between journalists and management are not unusual, and there are often changes in journalism that lead to such conflicts (Orre 2001). These stories were all told by the interviewees over 50, and are examples of strong ethical stands closely connected to the journalist's ideals. These stories are examples of virtue ethics, the internalizing of certain norms that are in line with a journalist's professional identity. The journalist must act against those in power, if they are unjust and do not act in accordance with journalism ethics. The self-respect these actions sustain leads to human flourishing or eudaimonia (Borden 2007; Quinn 2007), but such actions almost always lead to economical hardship as well. These stories can be read in light of the theories of Neo-Aristotelian philosopher Alasdair MacIntyre (2007), who argues that narratives are crucial in the individual's quest to be ethical. He presents a triad: first, narrative selfhood, or the unity of self, as presented and understood through stories, second, a quest for the good, and third, a sense of tradition, which can either be family or clan tradition, or the tradition of a practice or profession. MacIntyre agrees with narrative research, which holds that human existence is primarily understood through stories, and argues that stories are particularly important with regard to how people learn to be ethical, by following examples or internalizing ideals. The tradition that is relevant to speak about here is of course the tradition of the journalist profession, which has formed certain core values (Carpentier 2005; Deuze 2005; Hanitzsch 2007; Koljonen 2009) that influence the narrative selfhood of journalists. The examples of journalists taking a stand presented 
above are related to how interviewees perceive their roles with respect to stakeholders such as the public, and to fellow journalists, whereas owners and management of media companies are the opponents. These examples suggest that the core values of journalism are still relevant, and that the interviewees show a high capacity for ethical reasoning and are also willing to suffer the consequences of their ethics. However, the connection between narratives and ethics should be explored further in future studies.

\section{Discussion}

The freelancers in Norrbotten conduct themselves according to journalistic ideals and make ethical considerations, but most of them sometimes do work that is not traditional journalism. Some spend the majority of their working hours on jobs in a boundary zone between journalism and information. The informants say that it is impossible to survive as a freelancer otherwise. Some informants assert that jobs in the borderland between journalism and information are not inferior, but rather superior to many journalistic assignments, for example the journalism of the local dailies. According to the interviewees, there have been changes in the media landscape, such as commercialization, which have lowered quality of journalism etc., but of course it is difficult to know whether these changes are just perceived or substantial ones. The blurring of borders between journalism and information was evident in the material, but at the same time it seemed crucial for the journalists to maintain these borders. The purpose of the boundaries was to guard the integrity, impartiality and trustworthiness of the journalist, which was interpreted as being a way to maintain a coherent narrative and self-identity (Giddens 1991; MacIntyre 2007). The story about the journalist self was held intact through the setting up of boundaries between different types of assignments. In this way, they could perform work tasks in information, and at the same time maintain a journalistic identity, or, as some would say, they could have their cake and eat it too. In other words, they were positioned by and positioned themselves in relation to a dominant journalism discourse that they at the same time reinforced and opposed.

The ethics of freelance journalists are summarized in Figure 1. The journalist profession has been internally regulated by ideals, principles and norms, which are instructive for individual freelancers' everyday decisions. The ethical decisions of journalists are, how-

\section{Figure 1.}

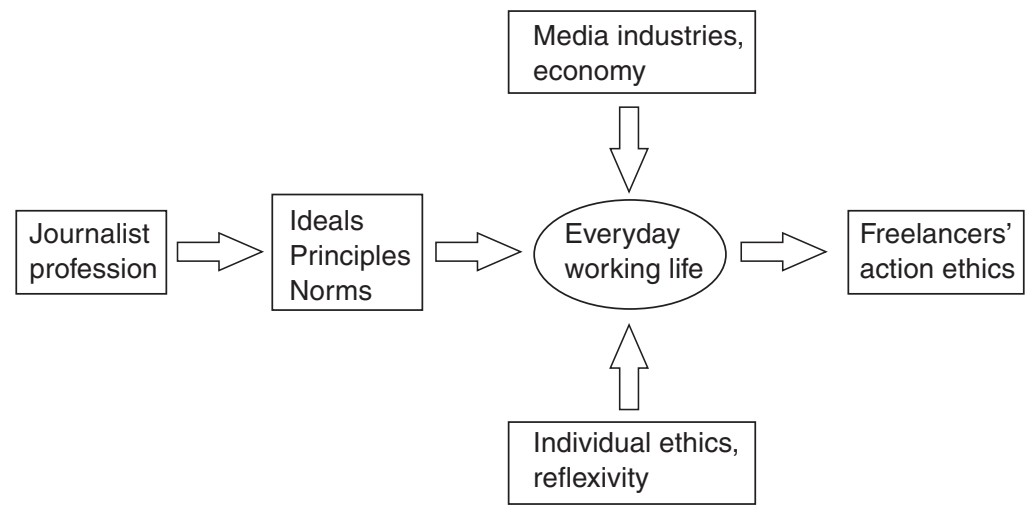


ever, also affected by business constraints, for example, commercialization of the media industries. These influences are processed individually, in a highly reflexive mode, and all directly influence individual action ethics. The only guard against unjust action is the internalization of a regulative ideal, proposed by virtue ethics, as the freelancer is mainly left on his/her own. The analysis shows that the informants reason and behave in accordance with an individual ethic, rather than with the professional principles of journalism.

\section{Notes}

1. Exceptions to this are, for example, an article about how to succeed as a freelancer (Bew 1998) and research on media workers' freelancing and enterprising careers (Baines 1999).

2. One of the journalists, however, owned her company, but preferred the "A-tax" schedule, where employers deduct and pay the taxes.

\section{References}

Alasuutari, P. (1997) “The Discursive Construction of Personality”, in Lieblich, A. \& R. Josselson (eds.) The Narrative Study of Lives. vol. 5. Thousand Oaks: Sage.

Atkinson, R. (1998) The Life Story Interview. Qualitative Research Methods Series 44, Thousand Oaks: Sage. Baines, S. (1999) "Servicing the Media: Freelancing, Teleworking and 'Enterprising' Careers", New Technology, Work and Employment (14)1: 18-31.

Beck, U. (2000) The Brave New World of Work. Cambridge: Polity Press.

Bew, R. (1998) "The Role of the Freelancer in Local Journalism", in Franklin, B. (ed.) Local Journalism and Local Media.

Borden, S. (2007) Journalism as Practice: MacIntyre, Virtue Ethics and the Press. Aldershot: Asgate.

Bivins, T. (2004) Mixed Media: Moral Distinctions in Advertising, Public Relations, and Journalism. Mahwah, New Jersey: Lawrence Erlbaum Publishing.

Börjesson, B. (2007) "Namnpublicering - en fråga om offentligt och privat" [Publication of names - A question of public and private], in Asp, K. (ed.): Den svenska journalistkåren [The Swedish Journalist Corps]. Department of Journalism and Masscommunication (JMG), Gothenburg University.

Carpentier, N. (2005) "Identity, Contingency and Rigidity: The (Counter)-Hegemonic Constructions of the Identity of the Media Professional", Journalism (6)2: 199-219.

Davis, A. (2003) "Public Relations and News Sources", in Cottle, A. (ed.) News, Public Relations and Power. London: Sage.

Deuze, M. (2005) "What is Journalism? Professional Identity and Ideology of Journalists reconsidered", Journalism (6)4: 442-464.

Deuze, M. (2007) Media Work. Cambridge: Polity Press.

Ekström, M. \& S.A. Nohrstedt (1996) Journalistikens etiska problem [The ethical problem of journalism]. Stockholm: Rabén Prisma.

Foucault, M. (1974) The Order of Things. London: Tavistock/Routledge.

Gardner, H., M. Csikszentmihalyi \& W. Damon (2001) Good Work: When Excellence and Ethics Meet. New York: Basic Books.

Giddens, A. (2008) The Constitution of Society: Outline of the Theory of Structuration. Cambridge: Polity Press.

Giddens, A. (1991) Modernity and Self-Identity: Self and Society in the Late Modern Age. Stanford: Stanford University Press.

\section{Acknowledgements}

I would like to thank Karin Sjöberg, Kari Koljonen, Cecilia Mörner, the research seminar at the Department for Music and Media, Luleå University of Technology, the anonymous reviewer of Nordicom Review, and Ulla Carlsson, for helpful comments and critiques in different phases of writing this article. I am thankful to Sparbanken Nord for generously funding the research, but most of all to my interviewees, the freelance journalists of Norrbotten. Without them this research would not have been possible at all. 
Hanitzsch, T. (2007) "Deconstructing Journalism Culture: Towards a Universal Theory", Communication Theory (17)4: 367-385.

Hanitzsch, T. \& K. Wahl-Jorgensen (2009) "Introduction: On Why and How We Should Do Journalism Studies”, in Hanitzsch, T. \& K. Wahl-Jorgensen (eds.) The Handbook of Journalism Studies. New York: Routledge.

International Federation of Journalists (2006) The Changing Nature of Work: A Global Survey and Case Study of A-Typical Work in the Media Industry. Research Report. URL (consulted 2009-11-06): http://www. ifj.org/assets/docs/068/112/3fbf944-95ebe70.pdf

Johansson, A. (2005) Narrativ teori och metod: Med livsberättelsen i fokus [Narrative theory and method: With the life story in focus]. Lund: Studentlitteratur.

Kennedy, C. (2009) "Ledare: Journalistförbundets flathet hotar frilansares trovärdighet" [Editorial: The indulgence of the journalist union threatens the trustworthiness of freelance journalists], Scoop (2009)4.

Klaidman, S. \& T. Beauchamp (1987) The Virtuous Journalist. New York: Oxford University Press.

von Krogh, T. (2009) Medieetik [Media ethics]. Stockholm: SNS Förlag.

Koljonen, K. (2009) "Five Viewpoints to Change: The Key Relations of Journalism and the new Chapter in the Journalism Profession", Paper presented at the $19^{\text {th }}$ Nordic Conference for Media Research.

Kovach, B. \& T. Rosenstiel (2007) The Elements of Journalism: What Newspeople Should Know and the Public Should Expect. New York: Three Rivers Press.

Kunelius, R. (1996) The News, Textually Speaking: Writings on News Journalism and Journalism Research. Dissertation, Department of Journalism and Mass Media, Tampere University.

Kvist, L. (2009) "Frilans på två stolar OK för SJF" [Freelancer on two chairs is OK for the Swedish union of journalists], Scoop 2009/4.

Laclau, E. \& C. Mouffe (2001) Hegemony and Socialist Strategy: Towards a Radical Democratic Politics. London: Verso.

Lambeth, E.B. (1992) Committed Journalism: An Ethic for the Profession. Bloomington: Indiana University Press.

Larsson, L-Å (2009) "PR and the media: A collaborative relationship?”, Nordicom Review (30)1: 119-135.

Lieblich, A. \& R. Josselson (eds.) (1997) The Narrative Study of Lives. Thousand Oaks: Sage.

Löfgren Nilsson, M. (1999) På Bladet, Kuriren och Allehanda: Om journalistiska ideal och organiseringsprinciper $i$ den redaktionella vardagen [On The Sheet, The Courier and Miscellenaneous: About journalist ideals and organizational principles in the editorial everyday]. Dissertation, Department of journalism and mass communication, Gothenburg University.

MacIntyre, A. (2007) After Virtue. Notre Dame: University of Notre Dame Press.

Maynes, M.J., J. Pierce \& B. Laslett (2008) Telling Stories: The Use of Personal Narratives in the Social Science and History. Ithaca: Cornell University Press.

McAdams, D., R. Josselson, A. Lieblich (eds.) (2006) Identity and Story: Creating Self in Narrative. Washington: American Psychological Association.

Murdock, G. \& J. Wasko (eds.) (2007) Media in the Age of Marketization. Cresskill: Hampton Press.

Nygren, G. (2008) Yrke på glid: Om journalistrollens de-professionalisering [Profession on a slope: About the de-professionalization of the journalist role]. Stockholm: $\operatorname{Sim}(0)$.

Oakley, J. \& D. Cocking (2001) Virtue Ethics and Professional Roles. Cambridge: Cambridge University Press.

Orre, I. (2001) Reporterskap: Äventyr, irrbloss, dygder [Reportership: Adventures, will-o' the wisp, virtues]. Dissertation, KTH Royal Institute of Technology.

Ottosen, R. (2004) I Journalistikkens grenseland: Journalistrollen mellom marked og idealer [In the borderland of journalism: Journalism between market and ideals]. Kristiansand: IJ-forlaget.

Quinn, A. (2007) "Moral Virtues for Journalists”, Journal of Mass Media Ethics, 22(2\&3): 168-186.

Schudson, M. (2003) The Sociology of News. New York: Norton.

Starck, K. (2001) “What's Right/Wrong with Journalism Ethics Research?”, Journalism Studies 2(1): 133-152.

Svenska journalistförbundet (SJF) "Spelregler för press, radio och TV" [Rules for press, radio and TV], URL (consulted 2009-06-29): http://www.sjf.se/portal/page?_pageid=53,38437\&_dad=portal\&_ schema=PORTAL

Ward, S. (2009) "Journalism Ethics”, in Hanitzsch, T. \& K. Wahl-Jorgensen (eds.) The Handbook of Journalism Studies. New York: Routledge.

\section{Oral Sources}

Interview with female freelancer, 40+, 30-09-2008

Interview with female freelancer, 60+, 21-10-2008

Interview with male freelancer, 50+, 27-11-2008 


\section{Nordicom Review 33 (2012) 1}

Interview with male freelancer, 50+, 14-01-2009

Interview with male freelancer, 40+, 14-01-2009

Interview with female freelancer, 40+, 13-02-2009

Interview with male freelancer, 50+, 16-01-2009

Interview with male freelancer, 50+, 22-01-2009

Interview with female freelancer, 40+, 20-03-2009

Interview with male freelancer, 50+, 20-03-2009

Interview with female freelancer, 30+, 04-09-2009

Interview with female freelancer, 40+, 12-10-2009

Interview with male freelancer, 40+, 15-10-2009

Follow-up interview with female freelancer 40+, 21-10-2009

Meeting with the freelance club of Norrbotten in Piteå, presentation of preliminary results and feedback, 25-11-2009

Telephone conversation with the Swedish union of journalists, 03-12-2009

Telephone conversation with Marianne Edlund, the Swedish union of journalists, 03-12-2009

Email from Maria Tillström, the Swedish union of journalists, 15-12-2009 